\title{
EU AND UKRAINIAN INNOVATIVE EXPERIENCE IN EDUCATION: THE ORIENTATION POINT FOR VET OF UKRAINE
}

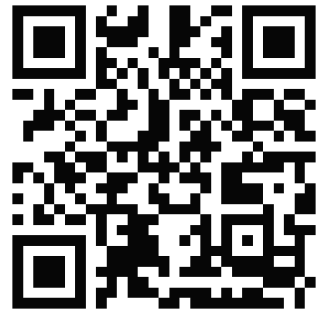

To cite this article:
Liudmyla Puhovska, Dr. Sc., Prof.

Chief Researcher, Institute of Vocational Education and Training,

National Academy of Educational Sciences of Ukraine

Kyiv, Ukraine

puhovska@ukr.net

https://orcid.org/0000-0002-0313-7761

\section{Snizhana Leu-Severynenko, PhD}

Senior Workforce Development Manager,

USAID Economic Resilience Activity,

FHI360 Global Education, Employment, and Engagement

Kyiv, Ukraine

snizhanaleu@gmail.com

https://orcid.org/0000-0001-8616-1005

Pukhovska, L. \& Leu, S. (2020). EU and Ukrainian innovative experience in education: the orientation point for VET of Ukraine. Education: Modern Discourses, 3, 42-49.

https://doi.org/10.37472/2617-3107-2020-3-04

\begin{abstract}
The article analyses the EU policy for innovations in the sector of vocational education and training (VET). It reveals the activity results of the European network "Innovations in vocational education and training" leading by the European Centre for the Development of Vocational Training (Cedefop). The paper identifies main development directions in VET systems and reviews its best practices of the EU countries based on the analysis of the experience of Campus of Occupations and Qualifications (France), Centre for Management, Training and Employment of Youth (Italy) and Centres of (Vocational) Excellence (Great Britain). Additionally, the following research covers some best practices in public and private educational sectors of Ukraine e.g. two university-based models of innovations eco-system realised via innovation hubs and startup schools, STEM-centres and Fabrication Laboratories. Therefore, the main ideas of positive European experience are identified being the valuable tool for developing the modern policy for innovations and VET in Ukraine. The identified local practices in education sector can be adapted to the capacity and needs of VET sector after additional and more detailed study.

Key words: Centre of Vocational Excellence European experience; innovations eco-system; innovations development; reforming; vocational education and training.
\end{abstract}

\section{INTRODUCTION}

In 2019 Ukraine took $47^{\text {th }}$ place in start-up rating of countries according to Global innovation index. In Ukraine the National Strategy of Education Development-2021 identifies the need in creating conditions for innovations development in order to enhance the investment 
attractiveness and competitiveness of Ukraine (National Strategy, 2013). The ground for this step is based in the new type of civilization that the humanity has recently had. It is innovative with the crucial characteristics of on-going changing and dynamics. The analysis of innovation background shows that most of innovations are based on start-up initiatives. In Ukraine the start-up support offered to the tech sector takes place in the "Ukrainian the Big Five of IT": Kyiv, Lviv, Dnipro, Kharkiv and Odessa e.g Startup.Network, Unit.City, Unit Factory, Sikorsky Challenge, Re: Actor, Fab Labs, etc. Governmental, non-governmental, corporate and venture initiatives for supporting start-up development have grown in recent years e.g. Ukrainian Start-up Fund, and contexts such as Best Invest, Start-up Battle by Startup.Network etc. Other mechanisms include investment tours to Ukrainian cities (UVCA), investment forums, symposia (Speed dealing, KIEF, Kyiv Investment Forum etc.), corporate challenges (Vernadsky Challenge, Science Battle (Carlsberg), Okko etc.).

Another indicator of innovative activity is dedicated to the state-of-arts of the vocational education and training system (VET) in the country and its capacity for creating and implementing innovations. Nowadays, Ukraine is fully engaged into the wide spectrum of trends and factors those influence and make the change in the development of European VET. According to the Bruges Communiquй (2012) that aligns with the Strategy Europe-2020 the increasing of innovative, creative and entrepreneur skills of VET students and the attendees of the continuous VET (CVET), gives the rise for moving into new paradigm of education. It balances the knowledge of professional and academic education and forces VET to become the driver of innovations in terms of streaming society changes (Bruges, 2010; ETF, 2020).

Under the Association Agreement between the European Union and Ukraine (2014) the nationwide reform of VET is in place in our country. It is based on the multilevel partnership in order to increase the prestige and status of VET and simultaneous promotion of economic growth, employment increase and regional development of Ukraine. There are lots of examples of VET innovative capacity and results in the worldwide and European environment, but pedagogical comparative science does history and customs-based study of their context e.g. political, economic, social and cultural and pedagogical. The check of best practices of innovative activity in European VET is an important source of information for the pedagogical society and scientific-based grounding of realization approaches and tools for leading foreign ideas in term of the conditions of Ukraine.

\section{LITARATURE REVIEW}

The educational innovations agenda is widely represented in the studies and researches of Ukrainian scientists. One of the most high-priority directions related to grounding the specifics of innovative technologies development and implementation in the training activity in terms of defining the professional essence of the activity is represented in the papers of O. Antonov, M. Artiushyna, I. Dychkivska, O. Dubaseniuk, V. Kremen, O. Kurbatov, V. Radkevych, H. Romanova, P. Saukh, S. Sysoieva and others. Most listed authors prefer studying the high education sector. However, the phenomenon of innovation in VET in foreign countries, in particular the experience of the European Union, remains little studied.

\section{METHODOLOGY}

This article looks at the above-mentioned problem through of the lenses of the international and comparative pedagogy. The study is aimed at presenting the best EU practices in the sector of VET and some examples of local innovation educational models, making general conclusions of their experience, producing and grounding meaningful ideas 
for their further implementation and adapting in the educational practice of Ukraine. The research is theoretical. The key methods are analysis, synthesis, abstracting, concretization, comparison, generalization and interpretation.

\section{MAIN RESULTS}

The comparative analysis of requirements for innovative education, formulated in European and national documents, expert groups papers and works of individual researchers, provides main characteristics and essential features of the future European innovative VET system able to:

- create the professional environment that meets an individual's abilities, needs and capabilities;

- be the multilevel vocational education in the form of a number of areas with educational programs that provide different training terms and sets of majors;

- arrange the continuation of professional programs of different levels;

- apply new organizational and functional forms for professional educational institutions based on functions distribution between educational institutions, enterprises and organizations those belong to the educational complex/cluster;

- create services to support the process of continual professional education, such as: adaptation, diagnostic, didactic, psychological centres etc.;

- support improvement of compatibility for national VET systems through justifying and implementing the European Qualifications Framework (EQF) and compatible National Qualifications Frameworks (NQF) that will help to ensure permeability between different sectors of education (higher qualifications frame covers both sectors with transparent links between ECTS units in higher education and ECVET - in VET), as well as the international recognition of qualification certificates;

- raise the quality of VET via developing the efficient quality systems (level of a VET institution, national and European level);

- use actively the innovative teaching methods and technologies;

- use efficiently modern IT and distance learning in VET in the context of creating a single European space of open education, etc. (EU, 2010; Bruges, 2010; Cedefop, 2014; Cedefop, 2019; European Commission, 2012).

At the current stage of development, each of these provisions is confirmed by the best practices developed in various European countries. At the European level, the thematic network "Innovations in vocational education and training", founded (InnoVET) in 2014 by the European Centre for the Development of Vocational Training (Cedefop) has become an important tool for dissemination of innovative educational practices. Its leading idea is to provide innovations in the labour market (LM) to reshape VET to make it more dynamic and innovative. As noted in the announcement for this event, in 2013 almost 22 million students studied in the EU high schools where half of them (49\%) were involved into VET programs. Developing their innovative ability and capacity can generate significantly the economic and social gains and financial revenues. It especially covers the urgent need of modern VET in new skills as a consequence of technological change and globalization. Through the European contextual advertising the InnoVET network Cedefop compiled national reports from all EU member states describing innovations in VET. The analysis and systematisation of these materials show that the experts represented a kind of innovations typology in modern European VET. In particular, it was found that systemic collaborative initiatives take the main place among innovations. They are the creation of new educational institutions by governments in tight partnerships with employers, international collaboration, national incentive schemes 
development to encourage cooperation between VET and higher education, etc. (Cedefop, 2015).

So, in 2019 the EU program "EU4Skills: Best Skills for Modern Ukraine" started to support the reform of VET in Ukraine. Its goal is to create the network of Centres of (Professional/ Vocational) Excellence, procurement of new equipment, skills improvement and upgrade for VET teachers and foremen of vocational training, develop new training programs and standards for students etc. In our opinion, they can be fully attributed to innovative, primarily aimed at collaboration and cooperation, as well as social partnership in general.

For a solid understanding of the problem, there is value in studying the experience the countries with VET models based on established institutional mechanisms, taking into account the principles of lifelong learning (LLL), etc. The Centre for Management, Training and Employment of Youth in Italy (Rome) with the symbolic name - "Open doors to the future" (Porto Futuro) is a good example of such an innovative institution. It combines the leading experience ideas of the French "Citedes Metries" and the Spanish "Porta 22" and since opening (2011) the Centre is aimed at reducing youth unemployment, increasing access to the LM and strengthening the social inclusion in times of severe economic crisis. The official data shows the relevance of this initiative as in 2014, the unemployment rate among the Italian youth aged 15-24 reached 44.5\%. The Centre's main efforts are directed "to facilitate the transition from the training system to the LM via providing the services on adequate employment and highquality management, employment opportunities for young people by means of internships and traineeship programs, and financial support" (European Commission, 2019).

An overview of new cooperation forms in Europe shows the ongoing increasing popularity of interaction between different types and kinds of education, including enterprises and research. The example of such innovation is the Campus of Occupations and Qualifications (Campus des mйtiers et des qualifications) in France. This kind of training institution links VET with the world of work, making it easier for workers to enter the LM. Being the element of a holistic VET system (IVET and CVET) campuses create links not only between levels of education, but also unite all organizations involved in VET e.g. vocational and public lyceums, apprenticeship centres, industry training councils, higher education institutions, research centres and companies, etc.

It should be noted that these officially recognized institutions provide educational services only in the sectors of aviation, public service, tourism, hotel and catering, industry and energy, metals and plastics, digital design. However, it is planned to spread this innovative experience to other sectors of national economy, and also to other regions of the country. This industry-specific consideration contributes to the qualitative implementation of the main tasks for campuses: a) assist and provide the access to the LM for young workers giving the opportunity to contact the companies in the sector of future professional activities directly while during their training; b) facilitate mixed career paths for young workers; c) stimulate creation of campuses in the sectors of creative work via implementing the international dimension (National reform programme, 2014). The important characteristic of French professions and qualifications campuses is that they function as providers of curriculum at various levels leading to professions and qualifications. The matching experience has been gained in Latvia, where new professional centres of competence also include secondary education programs etc.

A widespread innovation of our time is the Centres of (Vocational) Excellence $(\mathrm{Co}(\mathrm{V}) \mathrm{E})$ in VET sector. They implement various types of collaboration, namely: a) resources exchange (personnel, laboratories, instructional materials, etc.); b) attracting business; c) collective provision of certain services (development, procurement, collecting data on career opportunities, LM, etc.); d) coordination and rationalization of training proposals in order to optimize them and increase their efficiency; e) joint development of new teaching 
materials or use of new methods g) study of innovative practices in various VET institutions, etc. (Puhovska, 2017). Therefore, the $\mathrm{Co}(\mathrm{V})$ Es provide the typical activities and have common characteristics in approaches of pursuing excellence in a cluster of activities related to teaching and learning, namely: LM relevance, LLL, IVET and CVET, innovation and project-based learning, innovative curricula and pedagogy focused on transversal competences, transnational joint curricula, higher level VET programs and pathways, investing in the continuing professional development of teachers and trainers, guidance and validation of non-formal and informal learning etc. (European Commission, 2019).

Considering the prospects for development $\mathrm{Co}(\mathrm{V})$ Es in Ukraine (EU4Skills Project: Better Skills for Modern Ukraine) the experience of Great Britain can be addressed to. There are about 400 educational institutions in the VET sector with the status of a Centre of Professional Excellence. It is important to note that in the British context, the functioning of such centres has its own clearly expressed characteristics. They are not the special educational institutions called the Centres of Excellence, but a college or other institutions providing training services in VET sector. This status is considered to be an indicator of quality assurance for education services in a training institution. To have this status an institution must provide high quality teaching services and offer a range of courses that provide different learning paths starting from the third level of $\mathrm{NQF}^{1}$ and higher. The number of institutions in the UK aim primarily at theoretical substantiation of professional excellence by developing approaches to its understanding, approaches to forming, modelling and development (e.g. "Centre for skills, knowledge and activity efficiency of an organization", the University of Cambridge, CoEs assigned to higher education institutions etc.). At the same time, in VET sector regardless the name ${ }^{2}$ the functioning of such modern environments for obtaining highly qualified VET meeting the needs of employers and LM, technology development and promoting the prestige and demand for VET (IVET, technical, technological) among the population of this country (European Commission, 2019; Leu, 2017).

It is not as if there are no innovations in Ukraine. The analysis of Ukrainian context shows that most of best practices and new forms of training providers take place in the sector of higher education or private initiatives e.g. Fabrication Laboratory (Fab Lab), Innovation Hub (IH), STEM-centres etc. STEM-oriented centres are already in the systems of secondary and vocational education IHs and FabLabs are mostly university-based or belong to the sector of private or corporate education at enterprises.

STEM-centres aims at in-depth study of science, technology, engineering mathematics, forming engineering mindset and technical skills development are already popular in the network of secondary schools and in the private sector of educational services e.g. robotics centres. According to expert predictions, in 10-15 years many jobs that exist today will disappear, and new ones will take their place. New jobs will be mostly linked to the innovative technologies in science, engineering and mathematics with a focus on IT, robotics and programming. The demand for a talent pool of youth capable of filling these workforce needs to be addressed now so that students can recognize the real-life applications of STEM early in life. Therefore, it is important to start getting children and youth ready for new technologyrelated challenges as early as possible.

The logical continuation of STEM centres is represented in the model of Fabrication Laboratories - special prototyping workshops. They provide the environment and conditions to "think of and make anything". In 2001 a National Science Foundation grant to Neil Gershenfeld at Massachusetts Institute of Technology (MIT) started them to develop a way to transform "bits" to "atoms". In some time Fab Labs spread rapidly throughout the world and the Fab Foundation was created to manage the growth and evolution of Fab Labs. Today they

${ }^{1}$ Framework for Regulated Qualifications from 2015

${ }^{2}$ Centres of Excellence, Centres of Vocational Excellence or Centres of Competence 
are growing exponentially (doubling in size every 18 months) and today number over 1,000 in 87 countries.

Young people can acquire $21^{\text {st }}$ century skills in Fab Labs especially in combination with STEM education when teachers who know how to integrate the Fab Labs component into the curriculum. Most importantly, the learning occurring at Fab Labs leads to innovation and, with the right supports and linkages, can at the same time lead to entrepreneurship and job creation. Fab Labs present a unique opportunity to address both education and entrepreneurship in one platform. They have an extensive global network linked to MIT's Centre for Bits and Atoms. It provides global expertise and supports to regional communities while connecting them to the rest of the world. Because the investment in the physical infrastructure of a Fab Lab is reasonable for governments and businesses, it offers an affordable approach to growing job skills and economic opportunity in countries faced with the loss of traditional manufacturing jobs.

In Ukraine the network of Fab Labs consists of the ones based in universities ${ }^{3}$ and the ones in private sector ${ }^{4}$. They all follow the rules and approaches developed by the Foundation and communicate with each other creating regional and sectoral clusters. The obvious component of their activity is providing free of charge informational and training activities for locals.

The study shows the existence of two models of university-based innovation eco-system in Ukraine. They are Innovations Hubs (IH) and Start-up schools (SuS). IH is a place which provides facilities to nurture new ideas and help develop inquisitive perspective in youths of today. IHs serve as springboards for new ideas and innovation. They help the society and economy to face future challenges and meet rising aspirations of the growing population. In Ukraine the network of university-based innovation hubs is already in place. The most significant network is supported by the NGO Association Noosphere ${ }^{5}$. At present, seven universities of Ukraine grow, accelerate and develop the innovative ideas of their students at these modern environments for innovations ${ }^{6}$ and then try to find the investor at the international festival of innovations Varnadsky Challenge.

The IH model is also widely used in the private sector (both abroad and in Ukraine). Lots of companies start own innovations hubs to create, develop and promote innovations for their own better productivity and performance.

The SuS model is represented by the network of eleven Start-up Schools "Sikorsky Challenge" 7,8 . This all-Ukrainian network supports training students, postgraduates, professors and researchers on the issues of innovative entrepreneurship and start-up activities.

${ }^{3}$ National Technical University "Igor Sikorskyi Kyiv Polytechnic Institute", Open University "Ukraine", Odessa National Academy of Food Technology, Sumy State University etc.

${ }^{4}$ Fabricator (UnitCity, Kyiv), HUB LAB Odessa, IZOLAB (Kyiv), .buro (Odessa), Garage Hub (Kharkiv) etc.

${ }^{5} \mathrm{~A}$ Ukrainian non-profit, volunteer and non-governmental organization created to promote acquisition, application and dissemination of knowledge and to support educational initiatives

${ }^{6}$ National Technical University “Igor Sikorskyi Kyiv Polytechnic Institute”, Dnipro National University, Taras Shevchenko National University of Kyiv, National University of Water Management and Nature Resources Use, Kyiv Institute of Space research, Cherkasy State Technological University and Zhytomyr National Agroecological University

${ }^{7}$ The Innovation Holding "Sikorsky Challenge" LLC was founded in July of 2014. It is managed by a Director appointed by two individual owners and National Technical University of Ukraine "Igor Sikorsky Kyiv Polytechnic Institute". The Sikorsky Challenge was created to involve creative youth in innovative entrepreneurship. The Sikorsky Challenge promotes the growth of technological ideas, from the development and designing of business models to creating new innovative businesses, attracting investments and launching innovative startup companies.

${ }^{8}$ Pryazovskyi State Technical University, Donetsk National Technical University, V. Dahl East-Ukrainian National University, Donbass State Engineering Academy, National Technical University "I. Sikorskyi Kyiv Polytechnic Institute", Vinnytsia National Technical University, National Mining University, National University of Life and Environmental Sciences, Kherson State University, Sumy State University, I. Kondratiuk Poltava National Technical University, V. Dokuchaiev Kharkiv National Agrarian University 
They provide solid expertise support and insight to many up-and-coming entrepreneurs via multiple educational events, conferences, workshops, and competitions in innovative entrepreneurship.

Comparison of these two models shows their main distinction in sustainability. The IH model is more sustainable as it has the permanent support from one or more donor or investor institution(s) in contradistinction from the SuS model that depends a lot on donors' support which has rather ad-hoc character.

\section{CONCLUSIONS}

The conducted analysis made it possible to formulate the general conclusion about the emergence of new institutions (colleges, $\mathrm{Co}(\mathrm{V}) \mathrm{Es}$, campuses, etc.) in each EU country classified as educational innovations of our time. They emerged (and continue emerging) in the context of increased interaction between different types, kinds and levels of education with a significant expansion of the geography and range of educational institutions, including enterprises. These new institutions are being incorporated into the curriculum and teaching rethinking processes in VET. Without diminishing the importance of the phenomenon of "innovative practices" in VET of the EU countries, we note that innovation, as a rule, is a complex phenomenon, stimulated by relevant policies. As the study showed, the VET field is increasingly becoming a driver of innovation in Europe. Innovations in the LM are changing VET via contributing to its dynamism and innovation, and increasing its innovativeness. These processes can increase the human potential for renewal and changes in the economy and society as a whole. However, according to European scientists, Europe still does not fully use own potential and innovative resource of VET sphere to stimulate innovation in production and in society (Cedefop, 2015).

For forming modern innovative policy in VET field of Ukraine, the following ideas of the European experience can be valuable:

- reginal-based reforming the professional (vocational) education should take into account the adaptation of the European concept for public management in order to ensure the innovations management of client-managerial type;

- being the tool of reforming process in the regions, the development of $\mathrm{Co}(\mathrm{V})$ Es should make them the centres of innovations with the best reform practices, a platform for interaction between VET institutions, business, government and citizens, an example for disseminating pilot experience with other institutions in Ukraine etc.;

- it is expedient to use the experience of European countries in promoting innovations via facilitating local and national competitions in professional skills of the 21 century by $\mathrm{Co}(\mathrm{V}) \mathrm{Es}$, as well as transfer knowledge and experience gained during international competitions from professional skills etc.;

- develop and support understanding that VET and innovations are mutually supportive and interdependent areas.

Additionally, national VET institutions have good opportunity to adapt and use the experience already gained in high education and private sectors. However, this process needs additional more detailed study and development of appropriate approaches, management and monitoring tools and procedures.

\section{REFERENCES}

CEDEFOP (2014). Attractiveness of initial vocational education and training: identifying what matters. Luxembourg: Publications Office. Cedefop research paper; No 39. Retrieved from http://www.cedefop.europa.eu/EN/Files/5539_en.pdf 
CEDEFOP (2015). Thessaloniki, 3 December 2015. PRESS RELEASE. Innovation and training: partners in change. Retrieved from https://Documents\%20and\%20Settings/Admin/ Мои\%20документы/Downloads/2015-12-03_press_release_bn-innovation_en\%20(1). pdf

CEDEFOP (2019). 'Changing nature and role of vocational education and training (VET) in Europe' project, 2019. Retrieved from www.cedefop.europa.eu/en/events-and-projects/ projects/changing-natureand-role-vocational-education-and-training-vet-europe/ publications

ETF (2020). Centres of Vocational Excellence An engine for vocational education and training development. An international study. European Training Foundation, 2020. Retrieved from https://www.etf.europa.eu/en/publications-and-resources/publications/centresvocational-excellence-engine-vocational-education

Communiquй of the European Ministers for Vocational Education and Training, the European Social Partners and the European Commission, meeting in Bruges on 7 December 2010 to review the strategic approach and priorities. Retrieved from http://ec.europa.eu/ education/policy/vocational-policy/doc/brugescom_fr.pdf

European Commission (2019). Mapping of Centres of Vocational Excellence, Publications Office of the European Union, Luxembourg, 2019. Retrieved from http://www.scformazione. org/wp-content/uploads/2019/12/KE0119739ENN.en_.pdf

European Commission (2012). Communication from the Commission to the European Parliament, the Council, the European Economic and Social Committee and the Committee of the Regions. Rethinking Education: Investing in skills for better socioeconomic outcomes. Strasbourg, 20.11.2012 COM (2012) 669 final. Retrieved from https:// www.cedefop.europa.eu/files/com669_en.pdf

European Union (2010). Europe 2020: A strategy for smart, sustainable and inclusive growth. Communication from the Commission. - Brussels, 3.3.2010. Retrieved from http:// ec.europa.eu/eu2020/pdf/COMPLET\%20EN\%20BARROSO\%20\%20\%20007\%20-\%20 Europe\%202020\%20-\%20EN\%20version.pdf

National reform programme, France, May 2014. Retrieved from http://www.economie.gouv.fr/ files/programme-national-de-reforme-2014.pdf

National Strategy on Education Development in Ukraine 2021. Decree of the President of Ukraine as of 25.06.2013 № 344/2013. Retrieved from http://zakon2.rada.gov.ua/laws/ show $/ 344 / 2013$

Puhovska L., Leu S., Borodiienko O., Shymanovskyi M., Kravets Y., Melnyk O. (2017) Vocational schools in the EU countries: a practical guide. Kyiv: IVET NAES of Ukraine. Retrieved from https://lib.iitta.gov.ua/711447/3/Final-\%D0\%B4\%D1\%80\%D1\%83\%D0\%BA.pdf 